\title{
36.2 PSYCHROSPHERIC AND CONTINENTAL OSTRACODA FROM ANCIENT SEDIMENTS IN THE FLOOR OF THE MEDITERRANEAN
}

\author{
Richard H. Benson, Smithsonian Institution, Washington, D. C.
}

\begin{abstract}
Pliocene ostracods, typical of the upper psychrosphere of the open ocean floor, were found in drill cores of the Deep Sea Drilling Project (Leg 13) from the Tyrrhenian Basin at Site 132, and from the Balearic Basin at Site 134. No ostracods were recorded including other shallower species, in the cores examined from the Ionian Basin (Sites 125, 128) and the Levantine Basin (Site 129-Hole 129A) except in the latest Miocene portions thought to represent the "Melanopsis-Cyprideis zone" of the upper Messinian lago mare continental, alkaline facies. The deep-sea ostracod fauna is also known from outcrops in Italy, chiefly in early Pliocene sediments from immediately above the unconformity and conglomerate which commonly overlies strata of Messinian age. This considerable difference in faunas suggests a rapid change in regimen in the western Mediterranean from continental to deep, cold marine conditions. The absence of the psychrospheric ostracod fauna in the Pliocene of the Ionian Basin in the eastern Mediterranean may have been caused by the presence of an effective threshold between the two major basin complexes during this time. The Pleistocene sections of the cores of both the eastern and western basins contain the record of the Calabrian replacement of the psychrosphere by the thermosphere and the ultimate extinction in the Mediterranean of all but the most eurytropic psychrospheric ostracods. It is remarkable that no ostracods characteristic of normal marine sublittoral environments were found.
\end{abstract}

\section{INTRODUCTION}

This report is a brief summary of the ostracod evidence, as recorded in the cores of Leg 13 of the Deep Sea Drilling Project, indicating the presence of the psychrosphere in the western and central Mediterranean. It also includes a notation of the occurrence of the euryhaline continental ostracod Cyprideis found to the east in the Levantine Basin. More lengthy discussions of these faunas in the Mediterranean (especially from outcrops in Italy) and their significance have been, and are being, presented elsewhere (Benson and Sylvester-Bradley, 1971; Benson, in press; Benson and Ruggieri, in press).

\section{OSTRACODS IN THE CORES}

The ostracods are among the most important fossil representatives of the Neogene benthos found in the DSDP cores. Cores from seven of the 15 sites (Figure 1) available from Leg 13 were examined for ostracods. Samples from two holes in particular, Site 132 and Site 125, (Table 1) were examined in detail. The others (Table 2) were spot checked at important horizons.

The cores from the Mediterranean Ridge (Site 125) in the central Ionian Basin (latitude $34^{\circ} 37.49^{\prime} \mathrm{N}$ and longitude $20^{\circ} 25.76^{\prime} \mathrm{E}$; depth 2782 meters) were closely examined as representative of conditions just east of the
Sicilian-African marginal platform. No ostracods, shallow or deep species, were found in the cores of Site 125, suggesting abiotic conditions in the deeper basins to the east during some parts of the Neogene. This core included Messinian evaporites and Pliocene and Pleistocene marine sedimentary sequences (see descriptions in Chapters 7, 46, and 47 of this Volume). The second hole (Site 132) examined in detail yielded a sediment section of similar ages from the Tyrrhenian Basin (latitude $40^{\circ} 15.70^{\prime} \mathrm{N}$ and longitude $11^{\circ} 26.47^{\prime} \mathrm{E}$; depth 2813 meters). This core was selected as representative of the succession of events of the Mediterranean west of the Sicilian-African marginal platform. It is also close to the outcrop sections and known faunas in Italy. The cores of this site did have ostracods, including Agrenocythere pliocenica which is thought to be especially indicative of upper psychrospheric conditions.

Six of the nine core samples ( $120 \mathrm{cc}$ in size) of Site 132, in the Tyrrhenian Basin, ranging in age from late Messinian (Core 21) through early Pliocene (Core 19; below the horizon of extinction of Sphaeroidinellopsis seminulina and above the first appearance of Sphaeroidinella or equal to Cita's Globorotalia margaritae margaritae Lineage-zone) to early Pleistocene (Core 6; just above the level of the first appearance of Globorotalia truncatulinoides), yielded 52 specimens representing eight species of Ostracoda (Table 1). Two specimens of Agrenocythere pliocenica (Seguenza) 


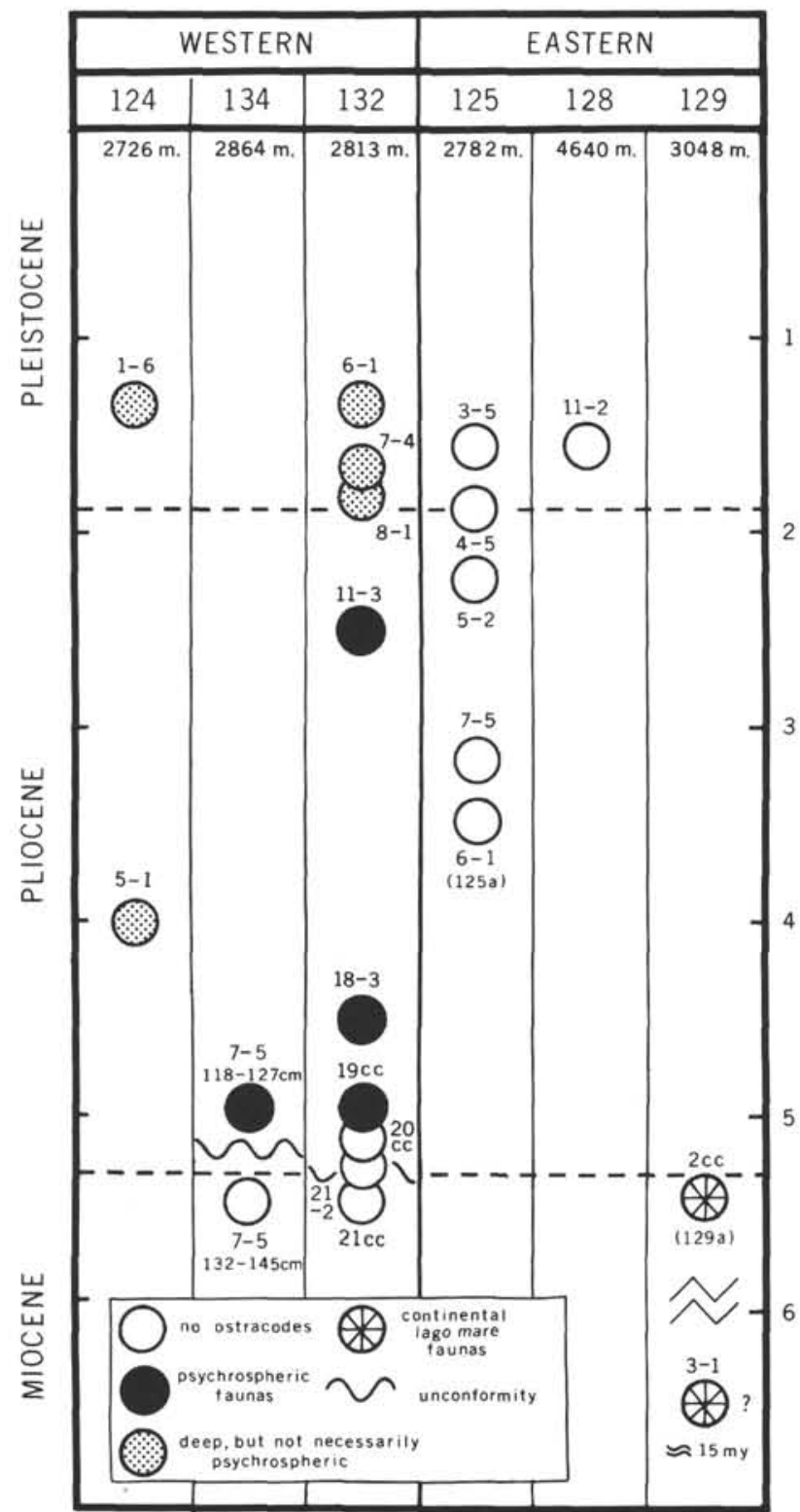

Figure 1. Distribution of the samples examined for ostracods from the cores of the Deep Sea Drilling Project, Leg 13 in the Mediterranean. The circles indicate the nature of the ostracod evidence found, the stratigraphic position (numbers indicate Core and Section), and the ages of the samples of particular drill holes (124 through 134). The depth of each of the drill-hole sites is indicated in meters at the top of the record of each hole represented. The notation "CC" indicates a core catcher sample and " $\mathrm{cm}$ " is the distance in centimeters down hole of the sample in a particular core section.

(Figure 2A) were found in the lower Pliocene (Tabianian) portion (Core 18) of the drill hole and four specimens in the late Pliocene (Pliacenzian) portion (equal to the nannoplankton zones of Discoaster surculus and Ceratolithus tricorniculatus, respectively 16 and 12). These cores are stratigraphically equivalent to the Trubi Formation of southern Sicily and southeastern Calabria (M. B. Cita, personal communication), where this form was also found
TABLE

Specimen Count from Site 132

\begin{tabular}{|c|c|c|c|c|c|c|c|c|c|}
\hline & \multicolumn{3}{|c|}{ Pleistocene } & \multicolumn{4}{|c|}{ Pliocene } & \multicolumn{2}{|c|}{ Miocene } \\
\hline Site & \multicolumn{3}{|c|}{132} & \multicolumn{4}{|c|}{132} & \multicolumn{2}{|c|}{1.32} \\
\hline Core (barrel) & 6 & 7 & 8 & 11 & 18 & & 20 & 21 & 21 \\
\hline Section & 1 & 4 & 1 & 3 & 3 & $\mathrm{C}^{\mathrm{b}}$ & $\mathrm{CC}^{\mathrm{b}}$ & 2 & $\mathrm{CC}^{\mathrm{b}}$ \\
\hline Interval (cm) & $16-24$ & $72-82$ & $54-63$ & $45-54$ & $4-13$ & & & $84-93$ & \\
\hline Penetration (m) & & & 70 & $100^{\mathrm{a}}$ & $165^{a}$ & & & & \\
\hline Bathycythere sp. & 1 & & & & & & & & \\
\hline Pseudocythere sp & 1 & & & & & & & & \\
\hline Krithe sp. & 4 & 8 & & 8 & & 3 & 0 & 0 & 0 \\
\hline Cytherella volgata & & 3 & 1 & 3 & & & & & \\
\hline $\begin{array}{l}\text { Henryhowella } \\
\text { asperrima }\end{array}$ & & & & 5 & & 2 & 0 & 0 & 0 \\
\hline $\begin{array}{l}\text { Bythoceratina } \\
\text { scaberrima }\end{array}$ & & & 1 & & & & & & \\
\hline $\begin{array}{l}\text { Agrenocythere } \\
\text { pliocenica }\end{array}$ & & & & 4 & 2 & & 0 & 0 & 0 \\
\hline $\begin{array}{l}\text { Bythocypris } \\
\text { obtusata? }\end{array}$ & & 6 & & & & & & & \\
\hline
\end{tabular}

aDepths approximate.

bCore catcher.

TABLE 2

Specimen Count from Sites 124, 128, 134, 129 and 129A.

\begin{tabular}{l|rr|rr|rrr}
\cline { 2 - 8 } & \multicolumn{2}{|r|}{ Pleistocene } & \multicolumn{2}{|c|}{ Pliocene } & \multicolumn{3}{|c}{ Miocene } \\
\hline Site & 128 & 124 & 124 & 134 & 134 & $129 \mathrm{~A}$ & 129 \\
Core (barrel) & 11 & 1 & 5 & 7 & 7 & 2 & 3 \\
Section & 2 & 6 & 1 & 5 & 5 & CCa & 1 \\
Interval (cm) & $74-$ & $33-$ & $125-$ & $118-$ & $132-$ & & $115-$ \\
& 90 & 64 & 133 & 127 & 145 & & 124 \\
\hline $\begin{array}{l}\text { Krithe sp. } \\
\text { Henryhowella } \text { sp. }\end{array}$ & 0 & 4 & & 1 & 0 & & \\
$\begin{array}{l}\text { Agrenocythere } \\
\text { pliocenica }\end{array}$ & & & 2 & 2 & 0 & & \\
$\begin{array}{l}\text { Cyprideis } \\
\text { pannonica }\end{array}$ & & & & 4 & 0 & & \\
\hline
\end{tabular}

acore catcher.

in outcrops. Agrenocythere pliocenica was also obtained from about the same horizon in Hole 134 in the Balearic Basin. Bythoceratina scaberrima (Brady) (Figure 2B) was found in the uppermost part of the Pliocene section (Core 8 , nannoplankton zone 18). This form is also a characteristic Mediterranean psychrospheric fossil ostracod in strata ranging in age (with intervals missing) from the Miocene of Gavdos Island near Crete to the lower Pleistocene of the Le Castella section of Calabria. Bathycythere Sissingh (Figure 2C) was found in the youngest sample studied (lower Pleistocene; Pseudoemiliania lacunosa nannoplankton zone). This psychrospheric ostracod sometimes occurs as a subfossil in the deeper Recent sediments of the present Mediterranean. The other genera, Cytherella, Krithe, Henryhowella, and Pseudocythere commonly are 

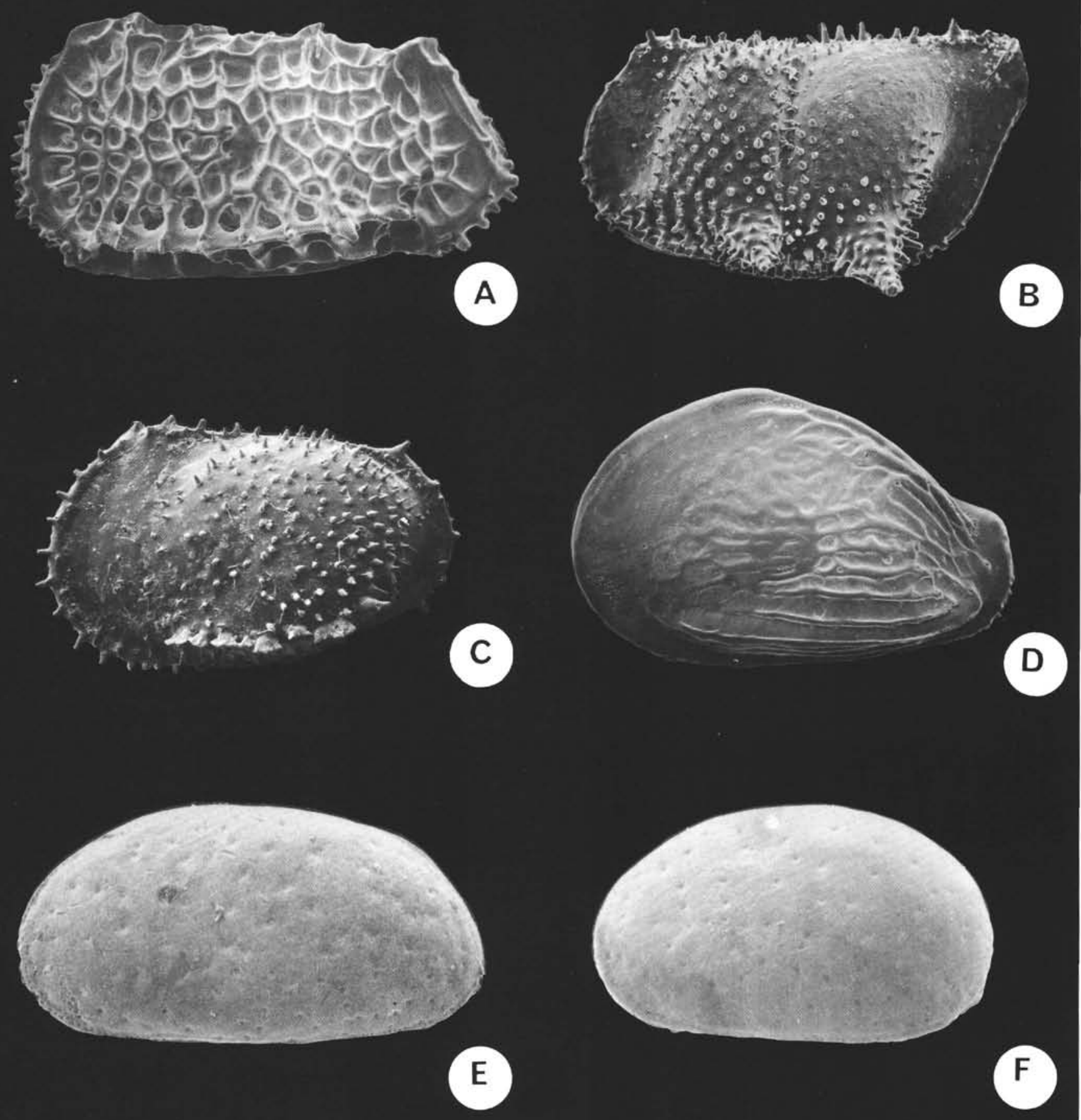

Figure 2. Ostracods representative of those taxa found in the DSDP 13 cores or discussed in the text, include four psychrospheric species (A-D) and two continental species $(E, F): A$, Agrenocythere pliocenica (Seguenza); B, Bythoceratina scaberrina (Brady); $C$, Bathyceratina $n$. sp.; D, Quasibuntonia radiotopora (Seguenza); $E$, $F$, Cyprideis pannonica (Mehés), male and female. All magnifications are approximately $\times 52$; specimens illustrated here were collected from outcrops in Italy (Benson and Sylvester-Bradley, 1971), except $C$, which was collected from the Atlantic. 
members of deep-water ostracod assemblages, but occasionally, and commonly in the case of Cytherella and Henryhowella, extend into shallower waters. Agrenocythere pliocenica and Bythoceratina scaberrima have become extinct in the present Mediterranean. Not present in the cores was Quasibuntonia radiatopora (Seguenza) (Figure 2D), which is a psychrospheric species found in outcrops in Italy.

No ostracods were found in six samples examined from the cores of Site 125 in the eastern Ionian Basin or from the one Pleistocene sample (Core 11, Sec. 2) obtained at 4640 meters water depth from Hole 128 in the Hellenic Trench. This is believed to be significant, as not finding ostracods of some kind in aquatic sediments is rare. The samples of Hole 125 (each at least $50 \mathrm{cc}$ in size) ranged in age from early Pliocene (lower Core 7, Site 132) to early Pleistocene (Core 3; equivalent to Core 7 of Site 132). Very few remains of benthic organisms were seen in any of these samples. Sapropels at several levels in the cores suggest local stagnation, which may have totally eliminated the sea floor fauna.
Two core samples of Miocene age were examined from Holes 129 and 129A (Levantine Basin, $34^{\circ} 20^{\prime} \mathrm{N}$ and $27^{\circ}$ $\left.05^{\prime} \mathrm{E}\right)$. These samples were especially interesting as they contained Cyprideis pannonica, sensu lato, a euryhaline (usually brackish water or "capsibrackish"; Krstic, 1971) ostracod (Figure 2E, F) common to the paratethys during late Miocene and early Pliocene. Its presence in the cores (Hole 129, Core 3, Sec. 1, 115-125 cm; Hole 129A, Core 2, core catcher) is especially interesting considering the present depths of the two sites (3,048 and 2,832 meters). This ostracod species is typical of the Melanopsis-Cyprideis zone of the lago mare deposits commonly found just above the Messinian evaporite sequence (Ruggieri and Greco, 1965; Ruggieri, 1967). It has been suggested in Chapter 10 that the specimens of Cyprideis pannonica in Core 3 of Hole 129 might represent downhole contamination. Eight specimens (Table 2) of Cyprideis were found in a relatively small quantity of sediment in this sample, but there is no suitable explanation for its appearance at this level.

In the western Mediterranean, in addition to cores from Hole 132 in the Tyrrhenian Basin, samples were also

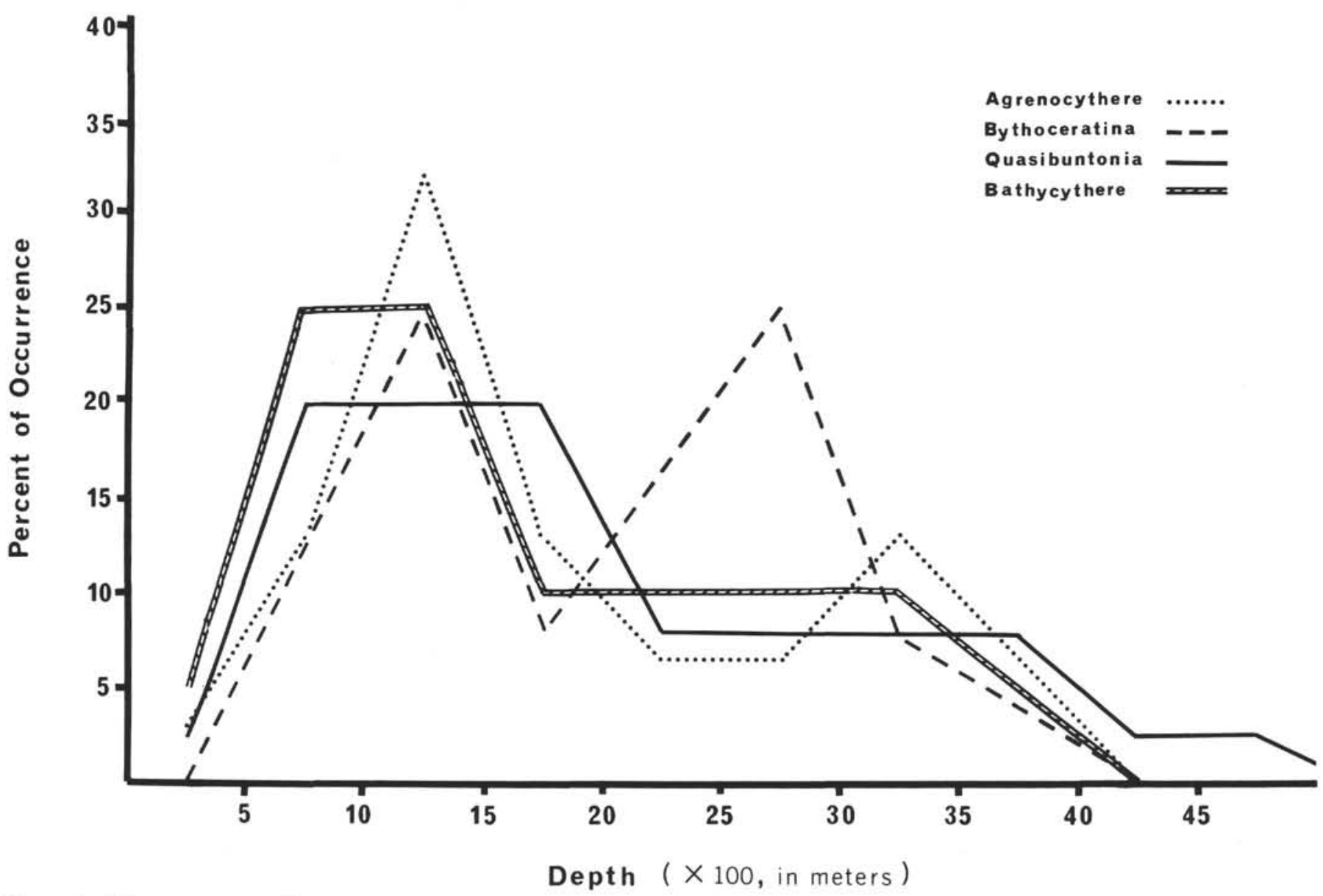

Figure 3. The recent world-ocean depth distribution of four psychrospheric ostracod genera found in Plio-Pleistocene sections of the DSDP 13 cores and in outcrops in Italy. The frequency distributions represent the likelihood of these taxa being found at any given depth interval of 500 meters from 0 to 5,000 meters in open ocean. Each line plot represents from about 30 to 80 recorded occurrences. 
examined for ostracods from Holes 124 and 134 from the west and east sides of the Balearic Basin $\left(38^{\circ} 52.40^{\prime} \mathrm{N}-04^{\circ}\right.$ $59.70^{\prime} \mathrm{E}, 2726$ meters; $39^{\circ} 11.70^{\prime} \mathrm{N}-07^{\circ} 18.25^{\prime} \mathrm{E}, 2864$ meters). The oldest sample of Hole 124 examined (Core 5, Sec. 1, 125-133 cm; lower Pliocene) contained two specimens of Henryhowella asperrima, which usually occurs in deep water and may be psychrospheric, but has a broad tolerance for shallow conditions as well. A younger sample from the same Hole 124 (Core 1, Sec. 6, 33-64 cm; Calabrian) contained four valves of a species of Krithe, which has an even wider depth range.

Two samples were examined from Hole 134 from just above (Core 7, Sec. 5, 118-127 cm; Pliocene, "Trubi" marl) and just below (Core 7, Sec. 5, 132-145 cm; Messinian dolomitic marl) the Miocene-Pliocene contact, which is marked by an abrupt change in lithology and an unconformity. No ostracods were found in the older sample beneath the contact. Seven ostracods were found in the younger Pliocene sample, including four specimens of Agrenocythere pliocenica. The ostracods are psychrospheric and suggest that the development of the psychrosphere was well advanced when these specimens were deposited. Considerable time seems to have elapsed between the formation of these two samples, now separated by only a few centimeters.

\section{THE FOSSIL AND MODERN DISTRIBUTION OF THE MEDITERRANEAN PSYCHROSPHERIC OSTRACODS}

Although elements of the world ocean psychrospheric ostracod fauna are known from strata in Italy ranging in age from Eocene to early Pleistocene (Benson and SylvesterBradley, 1971), they are now best known from the Pliocene "Trubi" Formation. The ostracod assemblage characteristic of this white marl, which is composed primarily of planktonic remains, contains several benthonic species indigenous to the Mediterranean. Nevertheless, their close phyletic relationship to their deep Atlantic counterparts is readily apparent. One of these, Agrenocythere pliocenica (Seguenza), is found widespread throughout Italy in deepwater Pliocene facies and is also well represented at DSDP Sites 132 and 134. Species of this genus are known to be living in the Atlantic and Indian oceans and are typical of facies believed to be formed in depths of more than 500 meters and less than 2,000 meters. The deep-sea affinities of the "Trubi" fauna were first noted by Ruggieri in 1953. Since then several of the more characteristic species have been identified by the author in several hundred samples taken from the open ocean floor itself. There seems little doubt about the upper psychrospheric origin of this assemblage, and about the fact that during the Pliocene the waters of the central Mediterranean were connected with, and extensions of, the cold water masses beneath the thermocline in the Atlantic.

Psychrospheric ostracods like those of the two DSDP holes in the Balearic and Tyrrhenian basins have been found in the Pliocene part of the San Riffilo Section from the northern Appennines near Bologna and in the lowermost part (Saito sample no. 6907) of the stratotype section of the Tabianian (lower Pliocene). It has also been found in the Calabrian and upper Pliocene sections at Le Castella, in the Pliocene near Santa Maria Catanzaro (Squillace), in the Crotone Basin region of Calabria, and along the southern coast of Sicily in the "Trubi" Formation from Agrigento eastward. It is frequently associated with Isodella, a small ahermatypic, deep-water coral. The overall faunal composition varies little, and the number of faunal elements or relative diversity is comparatively small. The psychrospheric fauna became extinct during the Calabrian as separation from the Atlantic, with the raising of the Gibraltar threshold, destroyed the psychrosphere in the Mediterranean.

From distribution data obtained from about 100 of the better documented samples available from the modern open ocean (Figure 3), the probable depth frequency of four of the most common ostracod genera represented in the Mediterranean Pliocene psychrospheric fauna have been plotted. The depth class intervals are given as 500 meters each over a range of 0 to 5,000 meters. The likelihood of occurrence of each taxon is represented as the relative percent of overall depth distribution. It is assumed that a fossil assemblage would most likely represent past depths of the threshold limiting access to the stock Atlantic fauna (assuming that water temperature gradients were roughly comparable) at that point on the bivariant plot where the greatest number of these occurrences coincide. The distribution over a known temperature range is very slight. The great majority of occurrences fall within the $4^{\circ} \mathrm{C}$ to $6^{\circ} \mathrm{C}$ range with few ever exceeding the $8^{\circ} \mathrm{C}$ level. At colder levels, another psychrospheric ostracod fauna becomes predominant. This deeper fauna is not yet known from the Mediterranean fossil record.

It should be emphasized that the comparison of fossil representation with modern depth or temperature distribution does not necessarily indicate the depth at which the animals lived in the Mediterranean, only the minimum depths of the restricting threshold separating the deeper basins of the Mediterranean from each other and ultimately from the Atlantic. This effect has been discussed in some detail elsewhere (Benson, in press). The fact that elements of the psychrospheric fauna entered the Mediterranean soon after the restrictive phase of the Messinian "salinity crisis" suggests a major tectonic change in the region of the threshold and does not necessarily indicate the depths of the basins themselves. The basins, within the Mediterranean such as the Tyrrhenian Basin, could not have changed in depth (foundering) as suggested by Selli and Fabbri (1971). During the time when they postulate a major transgression, the "middle Pliocene" (equal to Core 11, Site 132), the ostracodes indicate that this region had been long occupied by the psychrosphere.

The results of the analysis show that of the four included genera, Agrenocythere, Bathycythere, and Quasibuntonia (the larger, thinner forms with few ridges) individually tend to be found in depths greater than 500 meters and less than 2,000 meters. Bythoceratina (form related to $B$. scaberrima and $B$. vandenboldi), whose distribution is bimodal, may also be abundant at depths between 2,500 and 3,000 meters. In combination, the four genera are most likely to be found together in the modern oceans at depths of from 1,000 to 1,500 meters. More than thirty per cent of the reported findings of Agrenocythere 
are known from this particular depth interval. Because this genus is now fairly well known from the Recent and fossil record of the ocean floor, considerable weight is given to its occurrence and distribution in this analysis. From the analysis, it is concluded that the access of the Tyrrhenian Basin, as well as the areas of the Italian outcrops from which the fauna is also known, was broad (to accommodate sufficient water mass transfer to keep the heat budget at a temperature deficit) and deep to a level of somewhere between 1,000 and 1,500 meters below Pliocene sea level. Not accounted for in this estimate is the probability that Pliocene seas had a deeper thermocline (thicker thermosphere) which could more than offset the possible higher sea level of that time.

\section{THE MELANOPSIS-CYPRIDEIS FAUNA}

Melanopsis is a shallow, warm-water gastropod commonly found in many separate regions of the Mediterranean in Miocene lagoonal deposits with the euryhaline ostracod Cyprideis. These two fossils are especially typical of somewhat localized deposits immediately overlying the Messinian gypsum and dolomitic marls. These deposits were formed in what Ruggieri and Greco (1965) called lago mare, or sea lakes that represented restricted alkaline and saline waters caught in some of the basins after the lowering of sea level brought about a salinity crisis. The appearance of the Melanopsis-Cyprideis zone in the stratigraphic succession of the Mediterranean marks that interval of time between the salinity crisis of the Messinian formazione gessoso solfifera and the reinvasion of ocean waters from the Atlantic that brought with it the intrusion of the psychrosphere.

The presence of Cyprideis in Hole 129A in the Ionian Basin suggests that one of the lago mare was present in this region just after the salinity crisis. The geographic extent of such an alkaline lake in this region is difficult to speculate on at this time. Other such lakes are known to have been widesparead in the paratethys during this time interval (the Pontian or Pannonian of eastern Europe). The present position, about 3,000 meters below the surface of the Mediterranean, indicates considerable subsidence since its origin.

Cyprideis is a euryhaline ostracod that may constitute a significant portion of the benthic biomass of brackish water (and sometimes hypersaline or alkaline, calcium-rich lagoons and inland lakes or seas). It (Cyprideis littoralis) is a major constituent of several of the biofacies in the present Sea of Azov described by Zenkevich (1947, as stated by Caspers, 1957) and in the Caspian Sea (Zenkevich, 1957). Under these relic sea conditions, with salinities about one-third $(11-12 \%)$ those of normal marine, the ostracod Cyprideis may contribute up to 58 per cent of the biomass with as many as several thousand to hundreds of thousands of specimens per square meter. Their importance as contributors to the fossil record of the paratethys during the Pannonian (the "capsi-brackish" and Pontian phases) has been well documented in studies by Krstic (1971), among others. Although sometimes found in hypersaline as well as hyposaline environments (Gramann, 1971; Sandberg, 1964), the morphologic distinction usually present between these faunas (a high percentage of nodose forms in hyposaline conditions) may well be offset by an increase in calcium. There were no nodose forms found in DSDP Hole 129A thus leaving the question of brackishness open, but nevertheless demonstrating restricted continental conditions.

\section{CONCLUSIONS}

The late Miocene throughout most of the Mediterranean is represented by evaporite formation followed by deposition in alkaline lakes (lago mare) or a break in deposition. Within the lake deposits are found warm-and shallow-water gastropods, Melanopsis, and an abundant and characteristic ostracod, Cyprideis. The Pliocene began with an invasion of the sea from the Atlantic, and in some places this event is marked by a basal conglomerate. The ostracods of the western Mediterranean Pliocene deposits, both in the DSDP cores and in outcrops in Italy, are psychrospheric, coming from the floor of the Atlantic well below the thermocline. The subsequent deterioration and final destruction of the invading psychrosphere occurred during the Calabrian as the psychrospheric fauna is replaced in the deep basins by a descending thermospheric fauna. The invasion of ostracod "northern guests", which marks the beginning of the Pleistocene in the Mediterranean (Ruggieri, $1964,1967)$, is not recorded in the deep facies as these species (usually of Loxoconcha, Hemicythere and Cythere) are inner neritic. An exception is Cytheropteron testuodo Sars, which occurs at greater depths and whose first appearance in the Le Castella stratotype coincides with lowermost Calabrian (Colalongo, 1966). Although some of the eurythermic "deep-sea" ostracods have survived locally (and are found at DSDP Site 132), those endemic to the psychrosphere became extinct by Sicilian times.

As discussed elsewhere in this volume, the eastern basins of the Mediterranean were more restricted than those to the west (although there may still be some question as to where and how this restriction occurred). As yet there is no evidence of penetration of the psychrosphere as far east as DSDP Site 125 on the Mediterranean Ridge. The absence of any ostracods at this locality and the presence of other evidence such as sapropels suggests a restriction and separation from the west. Unresolved, however, is the presence of Pliocene psychrospheric ostracod faunas in south Calabria and in the eastern Po Valley near the Adriatic. These localities are obviously now east of the apparent barrier separating the eastern and western basins of the Mediterranean.

Also yet unresolved is the absence of shallow faunas representing the transition in depth between the Messinian continental lago mare stage and the Pliocene deep psychrospheric stage. Simple erosion of the threshold at the Iberian portal by intrusion of the Atlantic into the partially dried and topographically low Mediterranean basins would admit thermospheric ostracod faunas. Only a rapid major tectonic break in this barrier, however, would allow for the predominance of the deep benthic ostracod species. Although there is an interval of transition indicated in Hole 132, this change is from abiotic benthic conditions to psychrospheric. Shallow ostracods are missing. 


\section{ACKNOWLEDGMENTS}

I would like to acknowledge W. B. F. Ryan, Maria B. Cita, J. E. Hazel, Tsunemasa Saito, and Giuliano Ruggieri for their assistance in obtaining material and constructive remarks about this study. Dr. Cita was the first to notice Cyprideis in Hole 129A (see report of Chapter 10 of this volume). The study was sponsored by Smithsonian Research Foundation Grant No. SRF-43602 and National Science Foundation Grant No. GA-17325.

\section{REFERENCES}

Benson, R. H. Ostracodes as indicators of threshold depth in the Mediterranean during the Pliocene. In Stanley, D. J. (Ed.). The Mediterranean Sea: A natural sedimentation laboratory. Allen Press. (in press).

and Ruggieri, G. The Messinian hydrographic "crisis" as a problem in the interpretation of Mediterranean faunal history. Proc. of the Meeting on African Paleontology. Publ. Egyptian Geological Survey. (in press).

and Sylvester-Bradley, P. C., 1971. Deep-sea ostracodes and the transformation of ocean to sea in the Tethys. In H. J. Oertli (Ed.). Paleoecologie OstracodesPau, 1970. Bull. Centre Rech. Pau-SNPA, 5 suppl. 63, 15 figs., 1 table, 1 pl.

Caspers, H., 1957. Black Sea and Sea of Azov. Chapt. 25 In Hedgpeth, J. W. (Ed.). Treatise on Marine Ecology and Paleoecology. Geol. Soc. Am. Memoir 67 (1), 801.

Gramann, F., 1971. Brackish or hyperhaline? Notes on Paleoecology based on Ostracoda. In Oertli, H. J. (Ed.),
Paleoecologie Ostracodes-Pau, 1970. Bull. Centre Rech. Pau-SNPA, 5 suppl., 93, 1 plate.

Krstić, N., 1971. Ostracode biofacies in the Pannone; In Oertli, H. J. (Ed.). Paleoecologie Ostracodes, Pau 1970. Bull. Centre Rech. Pau-SNPA. 5 suppl., 391.

Ruggieri, G., 1953. Eta e fauna di un terrazzo marino sulla costa Ionica della Calabria. Giorn. Geol. Ann. Mus. Geol. Bologna. 23, 17, 5 plates. 1964. Ecological remarks on the present and past distribution of four species of Loxocondra in the Mediterranean. Publ. Staz. Zool. Napoli. 33 (suppl.), 515.

1967. The Miocene and later evolution of the Mediterranean Sea. Syst. Assoc. Publ. 7, 283.

1971. Ostracoda as cold climate indicators in the Italian Quaternary. In Oertli, H. J. (Ed.). Paleoecologie Ostracodes-Pau, 1970. Bull. Centre Rech. Pau-SNPA, 5 suppl., 285, 3 figs.

and Greco, A., 1965. Studi geologici e paleontologici su capo Milazzo con particulare regardo al Milazziano. Geol. Romana 4, 41, 11 plates.

Sandberg, P., 1964. The ostracod genus Cyprideis in the Americas. Stockholm Contri. Geol. 12, 1, 23 plates, 33 figs.

Selli, R. and Fabbri, A., 1971. Tyrrhenian: A Pliocene deep sea. Accad. Naz. dei Lincei (Roma). Series 8. 50, 105.

Zenkevich, L. A., 1947. Fauna and biological productivity of the seas. Vol. II, Seas of the USSR. Moscow, Sovyetskaya Nauka, 588 pages, 327 figs.

1957. Caspian and Aral Seas. Chap. 26. In Hedgpeth, J. W. (Ed.). Treatise on Marine Ecology and Paleoecology. Geol. Soc. Am. Memoir 67, (1), 891. 